\title{
International Organizations and Food: Nearing the End of the Lean Season?
}

\author{
Anna Wolkenhawer
}

\section{INTRODUCTION}

Food is many things. Most essentially, it is a source of nutrition-a source of life. Food is also culture, identity, and history. It provides autonomy and independence. And food embodies humans' relationship to the land. It is a source of income; a tradeable product and a global commodity. Food is a precious good and a vulnerable one too. Given its diversity of qualities and functions, how can food be delineated as an object of global social policy? If social policy is not only taken to include redistributive and protective interventions, but likewise those that aim to improve individuals' productive capacities and ability to earn an income (Mkandawire 2010 ), then food security comprises not only the "access to sufficient, safe and nutritious food that meets [people's] dietary needs and food

I thank Felix Anderl, Stephen Devereux, and the editors for much-valued feedback on an earlier draft. All remaining errors and omissions are my own.

\footnotetext{
A. Wolkenhauer $(\bowtie)$

Institute for Intercultural and International Studies (InIIS), University of Bremen, Bremen, Germany

e-mail: anna.wolkenhauer@uni-bremen.de

(C) The Author(s) 2021

K. Martens et al. (eds.), International Organizations in Global

Social Governance, Global Dynamics of Social Policy, https://doi.org/10.1007/978-3-030-65439-9_13
} 
preferences for an active and healthy life" (FAO et al. 2019, 186), but also access to the means of production.

At least since the food price hikes and subsequent crises of 2008 and 2011, food security has become a global concern. The Food and Agriculture Organization (FAO) of the United Nations estimated at the time that "the number of undernourished people in the world in 2008 [was] 915 million [...], the highest [absolute] number estimated over the past 3-4 decades" (FAO 2009, 104). Four famines were recorded between 2000 and 2011, all of them in Africa (Ethiopia, Malawi, Niger, and Somalia) (Devereux 2018a, 195). In 2019, the FAO found that the number of people who suffered from hunger was again on the rise, reaching over 820 million, with the largest share of undernourishment (almost 20 percent of the population) in Sub-Saharan Africa (FAO et al. 2019, 3). Achieving food security and the reduction of hunger are key aims in the Sustainable Development Goals (SDGs), they remain far from reached ten years out from the target year 2030.

International policies on food have historically been marked by a tension between visions of a global regulatory agency mandated to ensure equitable food supplies across the world and concerns about trade interests. While the more radical vision drove the initial post-war formation of the FAO, it was soon undermined by the widespread reliance on market forces, as promoted especially by the International Financial Institutions (IFIs). In the course of time, food policy became enmeshed with broader agendas of poverty reduction and sustainable livelihoods, while structural adjustment undercut productive capacities in the Global South. This history is important to understand not only the lack of success of international efforts at reducing global hunger, but also the current architecture of arguments in global food policy.

At present, the field of global food policy is marked by the reemergence of productive concerns, however, the realization of these concerns is somewhat constrained by the international free trade system institutionalized through the World Trade Organization (WTO). Within these boundaries, international agricultural institutions provide technical research, humanitarian relief, and linkages between food and other social policy programs, while the underlying structural causes for food insecurity largely remain in place. Thus, large parts of the populations in the Global South remain unable to secure sufficient food, despite working in agriculture.

The rest of this chapter proceeds as follows. The next section traces the history of the major international organizations (IOs) since their 
respective founding dates and discusses discursive and policy shifts up until the turn of the millennium. The third section then looks at contemporary debates around food and revisits the major IOs that were previously introduced. The chapter concludes that despite the narrowing of the discourse about food security, new movements can be distilled that promise to reopen some of the neglected debates about food and its production.

\section{History: IOs and FoOd Policy in the Twentieth Century}

\section{Constituting the Post-Colonial Order}

Food has been a global issue long before it became institutionalized as a policy field of international organizations after the Second World War (WWII). Questions of international trade and agricultural policies have long been interlinked, and during the colonial era, the securing of agricultural products was a central motivation for the European conquest of countries in the Global South (Orford 2015,9). The International Institute of Agriculture (IIA) was founded in 1905 and was the first formal initiative to create a global mechanism for exchanging information on commodities. Based in Rome, the IIA conducted a number of conferences between 1920 and 1934 and would later be integrated into the FAO (Staples 2006, 69; Liese 2012, 114). In 1937, the Permanent Agricultural Committee of the International Labour Organization (ILO) was set up to deal with problems related to agricultural labor (Nelson 1949, 525). In the interwar period, hunger came to be seen as a major global problem (Jachertz and Nützenadel 2011, 102), urban-rural disparities came to the fore (Forclaz 2019, 354), and knowledge about the importance of adequate nutrition grew (Staples 2006, 68-69).

Connecting nutrition and production, the FAO of the United Nations was conceived during the last years of WWII and officially founded through the approval of its constitution by representatives of 44 member states in October 1945 (Shaw 2007, 9). The preamble of the FAO's constitution described its mandate as raising nutrition levels, improving the efficiency of food production, contributing to rural development, and expanding the world economy overall (Phillips 1981, 9).

In 1946, a Rural Welfare Division was set up to act as an overarching unit that would connect the various technical divisions of the FAO, which 
were in turn responsible for fisheries, forestry, and other specialized fields (Forclaz 2019, 355). The Division was directed by Horace Belshaw, who adopted a holistic approach to rural development, attributed key importance to local knowledge and subjective measures of well-being, and was skeptical of overly top-down, expert-driven development programs (Forclaz 2019, 352-53, 359). The Division acted like the "conscience of FAO in rural welfare matters" (Phillips 1981, 128). In these early years, the FAO aimed to strengthen smallholder agriculture, as increasing their production would improve health and living standards as well as food availability (Forclaz 2019, 356). The approach taken by the FAO experts was informed by historical lessons, such as from Denmark's redistributive land reform and support to smallholders (Forclaz 2019, 358).

The FAO formulated a vision for a global food system which reflected the wider post-war optimism that global problems could be resolved through international cooperation (Jachertz and Nützenadel 2011, 99-100). One of the early propositions came from its first Director General, John Boyd Orr. He presented to the FAO's 1946 conference the idea of setting up a World Food Board for holding buffer stocks and for providing credit to developing countries (Jachertz and Nützenadel 2011, 109). The food held by the Board was supposed to be used for famine relief and sold at reduced prices to countries in need (Jachertz and Nützenadel 2011). It would also use its stockholding to prevent a fall in prices that might discourage food production (Staples 2006, 85-86). At the same time, it was hoped that the Board would thereby contribute to peace between nations (Staples 2006, 87).

While the conference initially approved of Orr's suggestion and set up a commission tasked with thinking out the details, the idea was eventually buried upon opposition from the US and the UK, who feared losing autonomy over trade policies (Jachertz and Nützenadel 2011, 110). Both were opposed to a strong FAO with regulatory powers and preferred an organizationally weak institution that would concentrate on offering technical advice, like the IIA had done previously (Jachertz and Nützenadel 2011, 107-08). Others, notably Latin American countries would have preferred an FAO with more far-reaching powers (Jachertz and Nützenadel 2011). Ultimately, instead of creating a World Food Board, it became a national undertaking for many countries to hold food buffer stocks, while international policies revolved around economic growth with the belief that this would eventually enable everyone to buy sufficient food (Staples 2006, 92-93). The 1950s were the height of modernization theories, 
which were focused on industrialization more than on agricultural development (Frey and Unger 2017, 11-12; Maxwell 2001, 39).

The FAO's second Director General, Norris E. Dodd, who was in office from 1948 until 1953, again tried to endow the FAO with powers to balance out price fluctuations in food commodities, but his proposal was equally rejected (Jachertz and Nützenadel 2011, 112). In the 1950s, the FAO then slowly gave up on its grand visions and resorted to focusing on technical assistance (Staples 2006, 99). Parallel to reducing its ambitions, the FAO's budget on the contrary grew. Supplementing its own small budget, the rapidly growing UN Expanded Program of Technical Assistance (EPTA, later to become the United Nations Development Program (UNDP)) doubled its funds to the FAO as part of its increased rural development aid (Forclaz 2019, 361). Consequently, the FAO's ability to undertake short-term technical assignments upon request by member governments grew (Forclaz 2019). The largest number of experts deployed came from the US and other Western countries and the way in which these technical missions worked was short-term, without much familiarity with the broader socio-economic contexts of receiving countries (Forclaz 2019, 363). The shift toward "piece-meal" technical tasks was further underlined in 1951, when the Rural Welfare Division was dismantled and reduced to a sub-division of the agriculture division in conjunction with the FAO headquarters moving from Washington to Rome (Forclaz 2019, 361; Phillips 1981, 128).

Food deficits gained renewed attention in the 1960s. Under the framework of its "Freedom from Hunger" campaign, the FAO increased its budget by 350 percent and further expanded its technical assistance programs in developing countries (Jachertz and Nützenadel 2011, 114; Phillips 1981, 72). In the same year, the United Nations adopted a resolution to distribute food through the UN system to "food-deficit" populations (Shaw 2009, 59). At the time, the US had been accumulating large food surpluses and had created its own "Office of Food for Peace" in the Executive Office of the president (Shaw 2009). The FAO warned that "dumping" large amounts of food could have negative consequences on receiving countries, and led the initiative to develop a system through which food aid could be used as part of the larger global developmental effort rather than as a political tool (Shaw 2009, 60; Shaw 2001, 3). This became the rationale for the creation of the World Food Program (WFP) in 1961 (Shaw 2009, 62-63). The US, however, made sure that this would coexist with, rather than replace, bilateral food aid programs (Shaw 
2009). The WFP was created with a dual mandate: to provide long-term developmental, and short-term humanitarian assistance (Shaw 2001, 2), with the relative weight between the two shifting back and forth over time. ${ }^{1}$ In the first three decades after its creation, the WFP directed twothirds of its resources toward developmental interventions, mainly through "food for work" and school feeding programs, and one-third toward emergencies (Shaw 2009, 76). This would reverse in the 1990s (Shaw 2009). Another important change concerned the sourcing of the food. The WFP shifted from using donated food from donor countries toward tapping into local and regional food markets (Maxwell 2008).

Last, the World Bank (WB) was one of the early organizations engaged in food policies after WWII. Under the World Bank Group, the International Development Association (IDA) was created in 1960 to offer loans on concessional terms, and the World Bank's overall aim turned toward poverty reduction (Shaw 2009, 71-76). The share of credit it provided to agricultural projects grew during the 1960s, not least due to the so-called Green Revolution during which crop yields in Latin America and Asia significantly increased between the 1950s and 1970s and thus required major investments in irrigation, drainage, and other related services (Pincus 2001).

In 1964, the World Bank decided to work together with UN specialized agencies, and a deal was made that the FAO would prepare agricultural projects for World Bank lending (Shaw 2009, 114). The World Bank itself increased the number of staff in its agriculture department too (Shaw 2009). After an initial period of mainly providing loans for large infrastructure projects (roads, harbors, airports, dams), the World Bank's investment portfolio broadened from the mid-1960s, and agriculture became one of the main foci (Stryker 1979, 326-27), "designed to benefit 'the poorest 40 percent" (Mkandawire 2010, 42). The IDA invested heavily in small farmers, supplying them with seed and fertilizer to foster cash crop production, which happened at the expense of the growth of local staple foods (Tetzlaff 2012, 266). Especially under the leadership of World Bank president McNamara (in office from 1968-1981), small farm development was seen as crucial for combining growth with poverty reduction (Pincus 2001).

The "Green Revolution" gave rise to high hopes in technology and science for resolving the world's hunger problem. While progress in

\footnotetext{
${ }^{1}$ https://www.wfp.org/history. Accessed May 16, 2020.
} 
natural sciences and technology had also been key for earlier agricultural revolutions (see Mingay 1977 on the UK), this marked the first large-scale and global "diffusion" of agricultural knowledge, such as that on highyielding crop varieties. The Rockefeller and Ford Foundations were at the forefront of developing an international agricultural research program, beginning with research on rice and wheat improvements (Hazell 2009, 1). Even though many of the technological solutions of the time were not appropriate for smallholder production (Harwood 2009), the "Green Revolution" was perceived as a success story of science, thereby laying the foundations for the significant role that global research organizations would come to play in food policy. Besides the two foundations, there was also the FAO, the UNDP, and the World Bank that began to lobby for donors to invest more funds into agricultural research (Shaw 2009, 66). This led to the creation of the Consultative Group for International Agricultural Research (CGIAR) in 1971, an umbrella body for research institutes that was initially tasked with studying possibilities of increasing output in staple foods (Shaw 2009, 66, 88, 154). The FAO, however, only reluctantly became a co-sponsor of CGIAR, as it meant giving away the lead it had in providing agricultural research by doing so (Shaw 2009, 96).

\section{The 1970s: High Time for Food Security}

In the early 1970s, the world's worst food crisis "in modern history" (Shaw 2010, 664), which included famines in the Sahel, Bangladesh, and Ethiopia (Devereux 2000,6), led the FAO to propose an international initiative for world food security and for setting up an early warning system (Phillips 1981, 74). At this time, the FAO was roughly half financed through the UNDP and half financed through extra-budgetary sources like trust funds (earmarked funds from donors for specific countries) (Phillips 1981). In 1974, a World Food Conference (WFC) was convened in Rome, though not on the FAO's premises (Shaw 2009, 96). Nonetheless, it still organized much of the program and managed to gain political support for many of its proposed activities. These included setting up a Global Information and Early Warning System (GIEWS) and strengthening its work on pesticides, seeds, plant and animal diseases, nutrition, extension, research, and training (Phillips 1981, 75). One of the goals defined at the WFC was the eradication of hunger, malnutrition, and food insecurity within a span of ten years (Martha 2009, 451). In the subsequent years, member governments agreed to increase the FAO's budget, though 
simultaneously suggested that it divert some of its resources away from headquarters (which was perceived to be overstaffed) into country offices (Phillips 1981, 75). After a review, some areas of the FAO's work were scaled down, including activities related to economic policies and world agricultural development, while the new short-term Technical Cooperation Program was initiated (Phillips 1981).

The 1974 conference also led to the establishment of various new institutional bodies. One of them was the Committee on World Food Security (CFS), an intergovernmental committee within the FAO tasked with serving as a forum for reviewing and following up on the decisions made at the conference (CFS 2015, 1). Another one was the shorter-lived World Food Council. Created in 1974, it was meant to function as "a political overview body and was to serve as the eyes, ears, and conscience of the UN system regarding world food security issues" (Shaw 2010, 664). Its coordination mandate allowed the president of the WFC to attend meetings of the governing bodies of the relevant UN agencies, in addition to holding meetings with their executive heads individually and collectively (Shaw 2010, 676). However, while given huge responsibilities, the WFC never received enough resources or authority and was dissolved in 1993 (Shaw 2010,690).

Finally, a new international financial institution was created in 1977 following the recognition during the 1974 conference that investments in food and agricultural production needed to be significantly increased (Martha 2009, 451). The International Fund for Agricultural Development (IFAD) was to be funded by voluntary contributions, a large share of which was to come from OPEC countries. It initially focused on funding food production in the poorest developing countries (Martha 2009, 453), and later diversified into other areas, such as rural finance, fisheries and livestock, irrigation, and rural poverty reduction more generally (Shaw $2009,143-45)$. As contributions remained behind commitments, IFAD became a small provider of grants and loans when compared to the World Bank and regional development banks (Shaw 2009, 63, 87). ${ }^{2}$ Nonetheless, it is the only IFI that has the mandate to invest its resources exclusively into agriculture in developing countries (Martha 2009: 457).

Throughout this period, the relative weight of the World Bank grew. Against an overall rise in World Bank lending and a growing number of World Bank staff, the increase in the share of agriculture in its lending

\footnotetext{
${ }^{2}$ https://www.ifad.org/en/history. Accessed May 16, 2020.
} 
portfolio from 18 percent in 1970 to 30 percent in 1981 was considerable (Pincus 2001). By the late 1970s, the World Bank had become the most powerful international financial institution for development (Stryker $1979,325)$, and debt owed by countries in the Global South started to accumulate (Tetzlaff 2012, 266). Apart from being the largest lender, the World Bank also began to dominate in terms of defining global development paradigms, based on the expertise of its economists from around the world (Tetzlaff 2012, 262-63). As a "knowledge bank", it has since had significant influence on the global development discourse (Van Waeyenberge and Fine 2011). It further increased its influence over CGIAR by increasing its funding and by persuading the CGIAR members to accept that their chairperson would be the vice-president of the World Bank (Shaw 2009, 114-15). Meanwhile, the FAO declined in relative importance and power (Unger 2019, 456).

The 1960s and 1970s were marked by governmental support for agriculture in the Global South. As in industrialized countries in the past, the strategies employed by states included land reforms, the provision of inputs and extension, national marketing agencies, governmental price setting, and stockpile management (Chang 2009). By taking account of and countering smallholder vulnerability, these could be classified as social protection policies (Devereux 2009, 6). While the FAO was supportive of such measures, it could not prevent them from becoming discredited during the neoliberal era of structural adjustment and agricultural liberalization.

\section{Neoliberal Shifts}

In the 1980s, after a short period of prioritizing rural poverty reduction, the World Bank shifted instead to concentrating on "eliminating all obstacles to a 'perfect market' as the presumed optimal path to growth" (Van Waeyenberge et al. 2011, 6). The bundle of neoliberal economic policy prescriptions commonly summarized as the "Washington Consensus" included the removal of subsidies, the deregulation and liberalization of trade, and the elimination of parastatal agencies (Oya 2004, 129). The national food security policies referred to above fell victim to these reforms, being perceived as largely inefficient and too costly. For Sub-Saharan Africa, the World Bank's "Berg Report", published in 1981, found that domestic pricing policies had been biased against agriculture, disrupted market mechanisms, and crowded out the private sector (World Bank 
1981; Loxley 1983; Devereux 2009, 6). The FAO underwent a policy shift too: from approaching food security at the national level (thus promoting grain-stockholding and self-sufficiency) to defining it at the individual and household level (for which imports were deemed more efficient) (Jarosz 2011). How and why this shift within the FAO occurred would merit further scrutiny.

During the 1980s, the World Bank provided so-called agricultural sectoral adjustment loans (ASALs) to countries of the Global South that were linked to the elimination of subsidies and the liberalization of prices for agricultural inputs and outputs (Pincus 2001). The envisaged solution was that by lifting price "distortions" imposed by the state, smallholders would be enabled to prosper freely (Oya 2004, 128). Having been identified as the problem, governing elites were now circumvented by donors, who preferred working through NGOs (Mkandawire 2010, 42-44). Overall, the reforms effectively dismantled the capacities of states to promote social and economic well-being. Their reduced investment in public goods for the agricultural sector coupled with trade liberalization threatened the survival of many farmers (Chang 2009, 2). Moreover, the wide-reaching financial market deregulation that began in this period enabled speculations on food, which eventually became one of the main drivers of the food price crises of 2008 and 2011 (Sonkin 2020).

During the height of structural adjustment, food security was reconceptualized. While it was still a concern to IOs in this period, it was largely decoupled from the production of food. As agricultural interventions by states had been discredited, structural adjustment reforms aiming at macroeconomic stability and economic growth were believed to ultimately also benefit poor people's ability to purchase food in the (globally connected) marketplace. According to the World Bank in the 1980s, the solution was "raising the real incomes of households so that they can afford to acquire enough food" (World Bank 1986, 5). Food security hence became mainly an issue of how to access it for consumption (Maxwell 2001, 24-25; Orford 2015, 6).

A critical juncture originated in the academic debate about famines. In 1981, Amartya Sen published his seminal work "Poverty and Famines" in which he pointed out that food crises were often not the outcome of insufficient food availability, but of insufficient access to food (Sen 1981). He suggested the framework of entitlements to make the case for paying more attention to individuals' and households' unequally distributed ability to access food, either through one's own production, by purchasing it 
from labor investment, or through food assistance (Sen; Devereux 2000, 19). With his intervention, Sen aimed to counter what had been received wisdom until then, including within the FAO: that food security was mainly a supply-side issue. Instead, he argued, one also needed to consider the inequalities and political dynamics within countries that accounted for people suffering from famines even in cases where food was available. While constituting an important intervention into an apolitical, technical discourse about food security, this work was simultaneously compatible with the interpretation that food security was achievable through a reduction of poverty and improved access to markets for the poor (Devereux $2000,20)$.

As access to food became a priority in the World Bank's food policy discourse, its lending to agriculture decreased. In its influential 1986 report entitled "Poverty and Hunger", the World Bank cited Sen's 1981 work to make the point that "[...] the loss of real income better explains why famines occur and who gets hurt" (World Bank 1986, 27). The focus in the international discourse shifted from supply to demand, and "entitlement, vulnerability and risk became the new watchwords" (Maxwell and Slater 2003, 532). It was only another four years until the World Bank began to promote targeted safety nets, perfecting an individualized perspective on poverty (World Bank 1990). The share of the World Bank's lending to agriculture dropped from 30 percent in the early 1980s to around 8 percent by the end of the millennium (Shaw 2009, 115). ${ }^{3}$ The resulting gap in lending to agriculture could not be compensated by IFAD, either, which had limited resources at its disposal (Martha 2009, 459).

The subordination of food security under the free trade paradigm was reinforced in 1995 by the formation of the WTO. Having previously been excluded from the General Agreement on Tariffs and Trade (GATT), agriculture became part of the agreement for the first time (FAO 1998). More than just regulating the international system, domestic policies also became the target of the rules due to their influence on trade (FAO 1998). While the arguments underlying these agreements were similar to those of the structural adjustment reforms, the WTO had longer-lasting effects on governments' ability to foster production by permanently enshrining rules

\footnotetext{
${ }^{3}$ The World Bank explains the decline with reference to the falling profitability of agriculture, the increased competition for aid from other sectors, and the opposition from developed country farmers as well as environmental groups (World Bank 2007, 42).
} 
about what types of interventions were permitted and which were not (FAO 1998; Margulis 2017, 50-51).

The FAO, meanwhile, reaffirmed food security and fighting hunger as their top priorities (Shaw 2009, 103). Because the long-term social effects of structural adjustment measures had proven disastrous for many countries in the Global South and had hit poorer farmers particularly hard (Oya 2004, 129-30), the awareness of poverty, undernourishment, and food insecurity began to rise again during the 1990s. A Summit on World Food Security was called by the FAO with the aim to renew international commitments. ${ }^{4}$ The Summit took place in November 1996 and a target was set to halve the number of people who were undernourished by 2015 , measured against the year 1990 (Devereux 2018a, 185). The definition of food security cited in the introduction of this chapter was also born at that summit, and has since become widely accepted (Margulis 2017, 29-30).

\section{IOs and Food Policy Since the Turn of the NeW Millennium}

\section{Consensus and Critique}

In 2003, Maxwell and Slater nostalgically asked: "Remember 'food policy'? It is what some of us used to do before we discovered 'food security" (Maxwell and Slater 2003, 531). Food security has become the core concept and rallying point in international food policy discourse. The above historical account shows how food security has evolved into a central, yet unsuccessfully resolved global problem. This section is concerned with the period since the turn of the new millennium. Architecturally, there has emerged an apparent consensus among the main international organizations that has culminated in two sets of developmental goals. Shortly following the 1996 World Food Summit, the Millennium Development Goals (MDGs) were adopted, in which goal number one was to "eradicate extreme poverty and hunger", or more precisely, to "halve, between 1990 and 2015, the proportion of people who suffer from hunger". ${ }^{5}$ And in the SDGs that replaced the MDGs in 2015, goal number two was to "end hunger, achieve food security and improved nutrition and promote

\footnotetext{
${ }^{4}$ http://www.fao.org/wfs/index_en.htm. Accessed May 16, 2020.

${ }^{5}$ https://www.un.org/millenniumgoals/poverty.shtml. Accessed May 16, 2020.
} 
sustainable agriculture". ${ }^{6}$ Both have contributed to a common framework for international organizations working in food (Devereux 2018a, 185), including the FAO, the WFP, and the World Bank. ${ }^{7}$

Especially since 2008, global food policy initiatives have proliferated, and several international organizations have forged connections within this field (Fouilleux et al. 2017, 1660). Since 2017, the United Nations Children's Fund (UNICEF) and the World Health Organization (WHO) have joined the FAO, the WFP, and IFAD in publishing their annual flagship publication "The State of Food Security and Nutrition in the World", which serves to monitor the progress made on SDG number two (FAO et al. 2019, xvi). As a new body, the Global Agriculture and Food Security Program (GAFSP) was launched in 2010 by the G20, as a "global partnership" for channeling donor funds (from rich countries and the Gates Foundation) to "public and private actors along the entire agriculture value chain". ${ }^{8}$ It is administered by the World Bank (FAO et al. 2019, 1665) and its steering committee includes not only representatives of international organizations but also a few civil society groups. 9 Since the 1996 World Food Summit, advocacy for recognizing the right to food has also brought the global human rights regime into the picture (Margulis $2013,58)$. The capacities of the Committee on Economic, Social and Cultural Rights and the Human Rights Council to monitor and enforce the human right to food have been strengthened (Margulis 2013, 59). The FAO adopted voluntary "right to food" guidelines in $2004^{10}$ and since then, has made efforts to mainstream a rights-based approach into its food agenda, albeit with varying success (Anthes and De Schutter 2017). Last, the space occupied by the WFP in the new millennium is unclear owing to the dual nature of its mandate, which has been found to be perceived as somewhat confusing (MOPAN 2013). While its budget is several

${ }^{6}$ https://www.un.org/sustainabledevelopment/hunger/. Accessed May 16, 2020.

${ }^{7}$ http://www.fao.org/sustainable-development-goals/en/; https://www.wfp.org/zerohunger; https://www.worldbank.org/en/programs/sdgs-2030-agenda, all accessed May 16, 2020.

${ }^{8}$ https://www.gafspfund.org/approach. Accessed May 16, 2020.

${ }^{9}$ https://www.gafspfund.org/civil-society-organizations. Accessed May 16, 2020.

${ }^{10}$ Voluntary Guidelines to Support the Progressive Realization of the Right to adequate Food in the Context of National Food Security, adopted by the 127th Session of the FAO Council, 22-27 November 2004, see http://www.fao.org/3/j3893e/J3893e02.htm\#ad. Accessed May 16, 2020. 
times higher than that of the FAO, ${ }^{11}$ its emergency logistics skills have at times made a larger impression than its developmental food policy visions (Sabates-Wheeler and Devereux 2018, 31; Maxwell 2008).

As international organizations have failed to resolve the problem of global hunger while continuously reconstructing a hopeful narrative (Hickel 2017), the emergence of powerful civil society actors has brought important dimensions of the global food question back to the table (Duncan 2016). A well-known one is La Via Campesina, an umbrella movement of peasants and smallholders from around the world, that was founded in 1993 to connect struggles for farmers' sovereignty over land, seeds, agricultural practices, and food (Borras Jr 2008; Borras et al. 2015)..$^{12} \mathrm{La}$ Via Campesina has engaged with the FAO, which is interested in collaborative policy development and knowledge sharing (Claeys and Edelman 2020, 1). ${ }^{13}$ One recent success of civil society has been the adoption by the United Nations of the "Declaration on the Rights of Peasants and Other People Working in Rural Areas" in 2018 (Claeys and Edelman 2020 ); another one was the institutionalization of civil society participation in the Committee on World Food Security, whose secretariat is hosted by the FAO, in 2009 (Duncan and Barling 2012; Duncan 2016, 150). ${ }^{14}$

An important critic of the global trade system and its effects on food security was Olivier De Schutter, who served as UN Special Rapporteur on the Right to Food from 2008 until 2014 (McMichael 2014, 939; Orford $2015,7)$. He highlighted that foreign imports outcompeted local production and destroyed agricultural capacities in the Global South, and criticized the WTO for rendering domestic food reserves, the management of prices, and the cushioning of income volatility for the rural poor impossible (De Schutter 2011). He also advocated for better regulations of largescale land acquisitions and for obliging investors to operate in the interest of local peasants (McMichael 2014, 939). Last, when the WTO proposed to regulate the types of permissible food aid, the WFP intervened and launched a public media campaign against the WTO (Margulis 2013, 61).

${ }^{11}$ WFP had raised 7.2 billion USD in 2018 (https://www.wfp.org/overview), while the total FAO budget planned for 2018-2019 was 2.6 billion USD (http://www.fao.org/ about/how-we-work/en/, both accessed May 16, 2020).

${ }^{12}$ https://viacampesina.org/en/food-sovereignty/. Accessed May 16, 2020.

${ }^{13}$ http://www.fao.org/news/story/en/item/201824/icode/. Accessed May 16, 2020.

${ }^{14}$ http://www.fao.org/cfs/home/about/en/. Accessed May 16, 2020. 
But while the UN organizations have much normative and moral authority, the WTO ultimately makes the rules (Margulis 2013, 63).

\section{Production}

In the new millennium, food production is back on the agenda. As was described above, the focus had shifted since the early 1980s from questions of production to questions of distribution and access. For several reasons, the new millennium has seen a return to the concern of how to produce more food. Devereux calls this the "new productivist agenda" (Devereux 2018a). Given the accelerating effects of climate change, this agenda is inevitably linked to the question of how to make food production not only more yielding but also more "sustainable".

Especially in Africa, agricultural productivity has not substantially increased over the past 50 years so that the continent falls short of feeding itself (Devereux 2018a, 186-88). In light of global population growth, the imperative that results is commonly referred to as the "challenge of feeding 9 billion people" (Godfray et al. 2010). In 2009, the FAO wrote that food production needed to be doubled "[...] in order to feed a population projected to reach 9.2 billion by 2050" (FAO 2009, vi), and the World Bank even estimates that a 70 percent increase in food will be required. ${ }^{15}$ While the need to increase the overall amount of available food worldwide is highly disputed (Fouilleux et al. 2017), as the current amount could be sufficient if only it were better distributed, ${ }^{16}$ the "productivist agenda" has brought the important question of supporting smallholder agriculture back into focus.

One of the first signals of this move was the World Bank's 2008 World Development Report (WDR), entitled "Agriculture for Development" (World Bank 2007). The topic of that year's WDR surprised the development community, given that the World Bank had not paid much attention to agriculture since the 1980s, as indicated above. In fact, except for IFAD, all international financial institutions had reduced their relative share of lending to agriculture during the 1990s (Martha 2009, 458). In the report, the World Bank itself recognized that donor neglect had

\footnotetext{
${ }^{15}$ https://www.worldbank.org/en/topic/climate-smart-agriculture. Accessed May $16,2020$.

${ }^{16}$ https://www.oxfam.org/en/press-releases/world-food-day-there-enough-foodgrown-world-everyone-op-ed. Accessed May 16, 2020.
} 
contributed to an underinvestment in agriculture in the Global South (World Bank 2007, 44).

The report was seen as a welcome move back toward the unresolved issue of how to foster smallholder production, but criticisms mounted too. The main thrust of the WDR 2008 remained the focus on market-led agricultural development in which the "new role for the state" would consist of "providing core public goods, improving the investment climate for the private sector-and in better natural resources management by introducing incentives and assigning property rights" (World Bank 2007, 24). Such interventions, however, did not promise to resolve the problems created by dismantling states' ability to promote their own agricultural sectors in the Global South, and critics interpreted it as "an ongoing adherence to orthodoxy" (Akram-Lodhi 2008, 1155). Moreover, while paying lip service to peasants, the report failed to resolve the problems they faced in having to operate in a detrimental environment shaped by big agribusinesses and corporate power (Oya 2009, 595).

Raising agricultural productivity and production without further damaging the environment and climate is a widely shared concern. As one solution, the FAO and World Bank encourage techniques of conservation agriculture (World Bank 2012). ${ }^{17}$ The FAO additionally supports agroecology (FAO 2018) and organic farming (Morgera et al. 2012, v). For its part, the World Bank has promoted "climate-smart agriculture" since 2009 , which combines the aims of productivity increase, reduction of vulnerability to climate change, and reduction of emissions (i.e., productivity, adaptation, and mitigation). ${ }^{18}$ Critics, however, have argued that this concept remains vague enough for the agricultural "business as usual" to continue (Taylor 2018). Research plays an important role in reaching the vision of a "food system simultaneously capable of delivering greater volumes of more nutritious food with a lower environmental footprint". ${ }^{19}$ International agricultural think tanks have once again gained in importance, not least because state research agencies have suffered in the structural adjustment period (Chang 2009, 14).

While critics point to the conflict between free trade and peasant production, a popular attempt at reconciling both is the reliance on global value chains. According to the World Bank, increasing private sector

\footnotetext{
${ }^{17}$ http://www.fao.org/conservation-agriculture/en/. Accessed May 16, 2020.

${ }^{18}$ https://csa.guide/csa/what-is-climate-smart-agriculture. Accessed May 16, 2020.

${ }^{19}$ https://www.cgiar.org/research/research-themes/. Accessed May 16, 2020.
} 
investment in agricultural value chains will contribute to ending poverty and hunger (World Bank 2018). Whether smallholders can benefit from being part of agricultural value chains, however, remains far from clear (Joala et al. 2016). From a very different vantage point, though also aimed at connecting smallholders to markets, farming cooperatives have been rediscovered. Historically, the cooperative movement has been a powerful way of enabling smallholders to benefit from economies of scale while simultaneously serving as a collective body for interest representation and risk pooling (Wanyama et al. 2009). After having suffered considerably from the structural adjustment reforms (Wanyama et al. 2009), cooperatives are now being promoted again, most prominently by the ILO. In 2002, the ILO adopted its Promotion of Cooperatives Recommendation (No. 193) as a guide to governments for revising their cooperative laws and putting supportive policies in place (ILO 2014, xv). The ILO sees cooperatives as having the potential to offer their members decent jobs, better access to global, regional, and national (agricultural) markets, access to finance, infrastructure, and irrigation, as well as social security (ILO 2014; Pollet 2009).

\section{Protection}

A whole architecture of its own has been constructed from arguments about the (potential) linkages between social protection and food security. The new millennium has seen a wave of new social protection policies across the Global South. They are aimed at providing income security in times of risk during different stages of the life cycle and include social assistance programs (like cash transfers) and social insurance schemes (like unemployment benefits) (ILO 2017, xxix). Many international organizations are promoting the social protection agenda, though from very different conceptual and political angles (for an overview, see UNICEF 2019, 63-68). In 2012, the High-Level Panel of Experts of the Committee on World Food Security produced a report arguing that rights-based social protection could further the realization of the right to food (HLPE 2012, 11). Social protection can play several key roles in relation to food, not only in terms of its consumption but also in terms of its production (HLPE 2012; Devereux 2009).

An obvious way for social protection to contribute to food security is through social transfers, in kind or in cash. They can enable the poor to afford adequate food, and they can smoothen seasonal income 
fluctuations, especially for subsistence farmers. In many countries, smallholders depend on rainfed agriculture and have-depending on the rain pattern in their region-only one harvest season per year. This leads to insufficient access to income or food throughout several months of the lean season (Devereux and Tavener-Smith 2019). Social transfers can prevent harmful coping strategies such as reducing food intake or the sale of assets (Devereux and Tavener-Smith 2019).

By raising household incomes, social protection can improve nutrition through making more diverse foods available. Besides the ILO, ${ }^{20}$ UNICEF is one of the leading international organizations that promote rights-based universal social protection, and produced its first "Social Protection Strategic Framework" in 2012 (UNICEF 2019, 1). UNICEF recognizes the positive impact that social protection can have on the nutrition of children, as a "good consumption and diet diversification [are] a major focus of expenditure when families living in poverty receive cash transfers" (UNICEF 2019, 29). But they also point out that additional concerted interventions are needed to address undernutrition effectively (UNICEF 2019; see also Devereux 2018a, 194). UNICEF engages in programs aimed at improving the nutrition of mothers, pregnant women, children, and adolescents and includes, for instance, breastfeeding campaigns or the supplementation of micronutrients. ${ }^{21}$ For its part, the WFP connects nutrition, agricultural development, and social protection by sourcing "home-grown" food for school meals, thereby improving educational outcomes while also offering an additional market to local smallholders. ${ }^{22}$

Social protection can also have productive effects. Especially for smallholders, overcoming financing constraints is a key step toward increasing production; yet, the private credit facilities that were supposed to replace the former state-led ones have failed to meet this need (Chang 2009, 18-19). Cash transfers are thus a useful support for farmers to invest in agricultural inputs and assets, such as seed, fertilizer, implements, or the use of processing facilities. In 2003, social protection was stipulated as a

${ }^{20}$ https://www.ilo.org/global/topics/social-security/lang\%2D\%2Den/index.htm. Accessed May 16, 2020. While the ILO's Social Protection Floors, adopted in 2012, are a key step in building rights-based social protection systems, they do not dwell on issues of nutrition (Devereux 2018b).

${ }^{21}$ https://www.unicef.org/nutrition/index_action.html. Accessed May 16, 2020.

${ }^{22}$ https://www.wfp.org/home-grown-school-meals. Accessed May 16, 2020. This differs from USAID, for instance, which sources US food for its food aid. 
"corporate priority" by the FAO and is increasingly integrated into its assistance missions (FAO 2017, 1). It aims to expand social protection to rural people, to forge synergies between social protection and agriculture, to make agriculture nutrition-sensitive, and to use social protection for agricultural resilience (FAO 2017). Under its "From Protection to Production Project", the FAO, in collaboration with UNICEF, evaluates the productive effects of cash transfer programs. ${ }^{23}$ Other social protection schemes include insurance mechanisms that protect smallholders against droughts or crop failure (Sabates-Wheeler and Devereux 2018,6), and supporting rural organizations that can collectivize risks (FAO 2017).

In sum, the current social protection momentum offers a much-needed opportunity to bring back those agricultural policies that were previously dismantled during the neoliberal era.

\section{Conclusion}

Ensuring that all people across the world have access to food remains an unresolved problem. Despite many decades of investments by international organizations, the number of those living with hunger or undernourishment is on the rise, and the productive capacities of farmers in the Global South remain severely incapacitated. While the formal international architecture around food has failed to address the major underlying structural problems, a growing number of civil society and peasant movements pose vital questions about the current global capitalist order, thereby re-politicizing what has largely become a deceptively peaceful mishmash of micro debates. Not least thanks to the current attention to rights-based social protection, several public interventions that could potentially remedy some of the negative consequences of the neoliberal reforms have been rediscovered. The end of the lean season of global food policies might thus be in sight. But whether this momentum is utilized will also depend on the political power and effectiveness of organizations that could challenge the neoliberal paradigm, which has been successfully "embedded" (Duncan 2016) by the World Bank and the WTO.

As Orford has pointed out, the fact that making sure people have enough to eat has become a task for international organizations, who act

\footnotetext{
${ }^{23}$ http://www.fao.org/economic/ptop/home/en/. Accessed May 16, 2020.
} 
"on behalf of humanity as a whole" is in itself remarkable (Orford 2015, 9). After all, food production and consumption are fundamentally local activities. Solving the problem of their equitable distribution might need to start from there.

\section{REFERENCES}

Akram-Lodhi, A. Haroon. 2008. "(Re)Imagining Agrarian Relations? The World Development Report 2008: Agriculture for Development." Development and Change 39 (6): 1145-1161. https://doi.org/10.1111/j.1467-7660.2008. 00511.x.

Anthes, Carolin, and Olivier De Schutter. 2017. "The FAO as a Human Rights Organization: Advancing the Right to Food to Promote Public Health." CRIDHO Working Paper. Louvain.

Borras Jr, Saturnino M. 2008. "La Vía Campesina and Its Global Campaign for Agrarian Reform." Journal of Agrarian Change 8 (2-3): 258-289. https:// doi.org/10.1111/j.1471-0366.2008.00170.x.

Borras Jr, Saturnino M, Jennifer C Franco, and Sofía Monsalve Suárez. 2015. "Land and Food Sovereignty." Third World Quarterly 36 (3). 600-617. https://doi.org/10.1080/01436597.2015.1029225.

CFS. 2015. "The Committee on World Food Security: A Multi-Stakeholder, Evidence-Based Approach to Policy Making." Committee on World Food Security.

Chang, Ha-Joon. 2009. "Rethinking Public Policy in Agriculture: Lessons from History, Distant and Recent." Journal of Peasant Studies 36 (3): 477-515. https://doi.org/10.4324/9780203803691.

Claeys, Priscilla, and Marc Edelman. 2020. "The United Nations Declaration on the Rights of Peasants and Other People Working in Rural Areas." The Journal of Peasant Studies 47 (1): 1-68. https://doi.org/10.1080/0306615 0.2019 .1672665 .

Devereux, Stephen. 2000. "Famine in the Twentieth Century." IDS Working Paper. Sussex.

Devereux, Stephen. 2009. "Social Protection for Agricultural Growth in Africa." FAC Working Paper 10. Brighton: Future Agricultures Consortium.

Devereux, Stephen. 2018a. "Food Insecurity and Famine." In The Routledge Handbook of African Development, edited by Tony Binns, Kenneth Lynch, and Etienne Nel, 183-201. New York: Routledge.

Devereux, Stephen. 2018b. "Social Protection Floors and the Right to Food." In Recommendation on Social Protection Floors: Basic Principles for Innovative Solutions, edited by Tineke Dijkhoff and Letlhokwa George Mpedi, chapter 4. Alphen aan den Rijn: Kluwer Law International B.V. 
Devereux, Stephen, and Lauren Tavener-Smith. 2019. "Seasonal Food Insecurity among Farm Workers in the Northern Cape, South Africa." Nutrients 11 (1535): 1-21. https://doi.org/10.3390/nul1071535.

Duncan, Jessica. 2016. "Governing in a Postpolitical Era: Civil Society Participation for Improved Food Security Governance." In Advances in Food Security and Sustainability, Vol. 1, edited by David Barling, 137-161. Burlington: Academic Press.

Duncan, Jessica, and David Barling. 2012. "Renewal through Participation in Global Food Security Governance: Implementing the International Food Security and Nutrition Civil Society Mechanism to the Committee on World Food Security." International Journal of the Sociology of Agriculture and Food 19 (2): 143-161.

FAO. 1998. The Implications of the Uruguay Round Agreement on Agriculture for Developing Countries: A Training Manual. Rome: FAO.

FAO. 2009. "The State of Food and Agriculture 2009." Rome: FAO.

FAO. 2017. "Harnessing the Role of Rural Organizations: An Inventory of Practices." Rome: FAO.

FAO. 2018. "FAO's Work on Agroecology: A Pathway to Achieving the SDGs." Rome: FAO.

FAO, IFAD, UNICEF, WFP, and WHO. 2019. "The State of Food Security and Nutrition in the World 2019: Safeguarding against Economic Slowdowns and Downturns." Rome.

Forclaz, Amalia Ribi. 2019. "From Reconstruction to Development: The Early Years of the Food and Agriculture Organization (FAO) and the Conceptualization of Rural Welfare, 1945-1955." International History Review 41 (2): 351-371. https://doi.org/10.1080/0707533 2.2018.1478873.

Fouilleux, Eve, Nicolas Bricas, and Arlène Alpha. 2017. "Feeding 9 Billion People': Global Food Security Debates and the Productionist Trap." Journal of European Public Policy 24 (11): 1658-1177. https://doi.org/10.108 0/13501763.2017.1334084.

Frey, Marc, and Corinna R. Unger. 2017. "Rural Development in the Twentieth Century: International Perspectives: An Introduction." Comparativ. Zeitschrift für Globalgeschichte und vergleichende Gesellschaftsforschung 27 (2): 7-14.

Godfray, H. Charles J., John R. Beddington, Ian R. Crute, Lawrence Haddad, David Lawrence, James F. Muir, Jules Pretty, Sherman Robinson, Sandy M. Thomas, and Camilla Toulmin. 2010. "Food Security: The Challenge of Feeding 9 Billion People.” Science 327: 812-818. https://doi.org/10.1126/ science. 1185383 .

Harwood, Jonathan. 2009. "Peasant Friendly Plant Breeding and the Early Years of the Green Revolution in Mexico." Agricultural History 83 (3): 384-410. https://doi.org/10.3098/ah.2009.83.3.384. 
Hazell, Peter B.R. 2009. "The Asian Green Revolution.” IFPRI Discussion Paper Series. Washington D.C.

Hickel, Jason. 2017. The Divide: A Brief Guide to Inequality and Its Solutions. London: Penguin.

HLPE. 2012. "Social Protection for Food Security." Rome.

ILO. 2014. "Promoting Cooperatives - An Information Guide to ILO Recommendation No. 193." Geneva: ILO.

ILO. 2017. "World Social Protection Report 2017-19: Universal Social Protection to Achieve the Sustainable Development Goals." Geneva: ILO.

Jachertz, Ruth, and Alexander Nützenadel. 2011. "Coping with Hunger? Visions of a Global Food System, 1930-1960." Journal of Global History 6 (1): 99-119. https://doi.org/10.1017/S1740022811000064.

Jarosz, Lucy. 2011. "Defining World Hunger: Scale and Neoliberal Ideology in International Food Security Policy Discourse." Food, Culture and Society 14 (1): 117-139. https://doi.org/10.2752/175174411X12810842291308.

Joala, Refiloe, Phillan Zamchiya, Clemente Ntauazi, Patrick Musole, and Caesar Katebe. 2016. Changing Agro-Food Systems: The Impact of Big Agro-Investors on Food Rights. Cape Town: PLAAS.

Liese, Andrea. 2012. "FAO - Ernährungs- Und Landwirtschaftsorganisation Der Vereinten Nationen." In Handbuch Internationale Organisationen, edited by Katja Freistein and Julia Leininger, 113-118. Oldenbourg: De Gruyter.

Loxley, John. 1983. "The Berg Report and the Model of Accumulation in SubSaharan Africa." Review of African Political Economy 27: 197-204.

Margulis, Matias E. 2017. "The Forgotten History of Food Security in Multilateral Trade Negotiations." World Trade Review 16 (1): 25-57. https://doi. org/10.1017/S1474745616000410.

Margulis, Matias E. 2013. "The Regime Complex for Food Security: Implications for the Global Hunger Challenge." Global Governance 19: 53-67. https://doi. org/10.1163/19426720-01901005.

Martha, Rutsel Silvestre J. 2009. "Mandate Issues in the Activities of the International Fund for Agricultural Development (IFAD)." International Organizations Law Review 6 (2): 447-477. https://doi.org/10.116 3/157237409X477653.

Maxwell, Simon. 2001. "The Evolution of Thinking about Food Security." In Food Security in Sub-Saharan Africa, edited by Stephen Devereux and Simon Maxwell, 13-31. London: ITDG.

Maxwell, Simon. 2008. "WFP and Global Food Security: Memorandum Submitted to the UK Parliament." UK Parliament, House of Commons.

Maxwell, Simon, and Rachel Slater. 2003. "Food Policy Old and New." Development Policy Review 21 (5-6): 531-553. https://doi. org/10.1111/j.1467-8659.2003.00222.x. 
McMichael, Philip. 2014. "Historicizing Food Sovereignty." Journal of Peasant Studies 41 (6): 933-957. https://doi.org/10.1080/03066150.2013.876999.

Mingay, Gordon E. 1977. The Agricultural Revolution: Changes in Agriculture 1650-1880. London: Black.

Mkandawire, Thandika. 2010. "How the New Poverty Agenda Neglected Social and Employment Policies in Africa." Journal of Human Development and Capabilities 11 (1): 37-55. https://doi.org/10.1080/19452820903481400.

MOPAN. 2013. "Institutional Report: World Food Programme (WFP), Volume I.” Multilateral Organisation Performance Assessment Network.

Morgera, Elisa, Carmen Bullón Caro, and Gracia Marín Durán. 2012. "Organic Agriculture and the Law." FAO Legislative Study. Rome.

Nelson, Lowry. 1949. "The Work of the Permanent Agricultural Committee of the International Labour Office." Journal of Farm Economics 31 (3): 524-528.

Orford, Anne. 2015. "Food Security, Free Trade, and the Battle for the State." Journal of International Law and International Relations 11 (2): 1-67.

Oya, Carlos. 2004. "Sticks and Carrots for Farmers in Developing Countries: Agrarian Neoliberalism in Theory and Practice." In Neoliberalism: A Critical Reader, edited by Alfredo Saad-Filho and Deborah Johnston, 127-134. London: Pluto Press.

Oya, Carlos. 2009. “The World Development Report 2008: Inconsistencies, Silences, and the Myth of 'win-Win' Scenarios." Journal of Peasant Studies 36 (3): 593-601. https://doi.org/10.1080/03066150903142949.

Phillips, Ralph W. 1981. FAO: Its Origins, Formation and Evolution 1945-1981. Rome: FAO.

Pincus, Jonathan. 2001. "The Post-Washington Consensus and Lending Operations in Agriculture: New Rhetoric and Old Operational Realities." In Development Policy in the 21st Century, edited by Ben Fine, Costas Lapavitsas, and Jonathan Pincus, 182-218. London: Routledge.

Pollet, Ignace. 2009. "Cooperatives in Africa: The Age of Reconstruction Synthesis of a Survey in Nine African Countries." Coop Africa Working Paper. Geneva.

Sabates-Wheeler, Rachel, and Stephen Devereux. 2018. "Social Protection and the World Food Programme." World Food Programme Occasional Papers. Rome.

Schutter, Olivier De. 2011. The World Trade Organization and the Post-Global Food Crisis Agenda: Putting Food Security First in the International Trade System. Brussels: University of Louvaine

Sen, Amartya. 1981. Poverty and Famines: An Essay on Entitlement and Deprivation. Oxford: Clarendon Press.

Shaw, D. John. 2001. The UN World Food Programme and the Development of Food Aid. Basingstoke: Palgrave Macmillan. 
Shaw, D. John. 2007. World Food Security: A History since 1945. Basingstoke: Palgrave Macmillan.

Shaw, D. John. 2009. Global Food and Agricultural Institutions. London and New York: Routledge.

Shaw, D. John. 2010. "The World Food Council: The Rise and Fall of a United Nations Body." Canadian Journal of Development Studies 30 (3-4): 663-694. https://doi.org/10.1080/02255189.2010.9669320.

Sonkin, Flora. 2020. "Recipe for Disaster: The IMF and World Bank's Role in the Financialisation of Food and Agriculture." London: Bretton Woods Project.

Staples, Amy L. S. 2006. The Birth of Development: How the World Bank, Food and Agriculture Organization, and World Health Organization Changed the World, 1945-1965. Kent, Ohio: The Kent State University Press.

Stryker, Richard E. 1979. "The World Bank and Agricultural Development: Food Production and Rural Poverty." World Development 7 (3): 325-336. https:// doi.org/10.1016/0305-750X(79)90060-3.

Taylor, Marcus. 2018. "Climate-Smart Agriculture: What Is It Good For ?" The Journal of Peasant Studies 45 (1): 89-107. https://doi.org/10.1080/0306615 0.2017 .1312355 .

Tetzlaff, Rainer. 2012. "Weltbank." In Handbuch Internationale Organisationen, edited by Katja Freistein and Julia Leininger, 261-273. Oldenbourg: De Gruyter.

Unger, Corinna R. 2019. "International Organizations and Rural Development: The FAO Perspective." International History Review 41 (2): 451-458. https://doi.org/10.1080/07075332.2018.1460387.

UNICEF. 2019. "UNICEF's Global Social Protection Programme Framework." New York: UNICEF.

Waeyenberge, Elisa Van, and Ben Fine. 2011. "A Knowledge Bank?" In The Political Economy of Development: The World Bank, Neoliberalism and Development Research, edited by Ben Fine, Elisa Van Waeyenberge, and Kate Bayliss, 26-46. London: Pluto Press.

Waeyenberge, Elisa Van, Ben Fine, and Kate Bayliss. 2011. "The World Bank, Neo-Liberalism and Development Research." In The Political Economy of Development: The World Bank, Neoliberalism and Development Research, 3-25. London: Pluto Press.

Wanyama, Fredrick O., Patrick Develtere, and Ignace Pollet. 2009. "Reinventing the Wheel? African Cooperatives in a Liberalized Economic Environment." Coop Africa Working Paper. Dar Es Salaam and Geneva.

World Bank. 1981. "Accelerated Development in Sub-Saharan Africa: An Agenda for Action." Washington D.C. 
World Bank. 1986. "Poverty and Hunger: Issues and Options for Food Security in Developing Countries." Washington D.C.

World Bank. 1990. "World Development Report 1990: Poverty.” Washington D.C.

World Bank. 2007. "World Development Report 2008: Agriculture for Development." Washington D.C.

World Bank. 2012. "Agricultural Innovation Systems: An Investment Sourcebook." Washington D.C.

World Bank. 2018. "Future of Food: Maximizing Finance for Development in Agricultural Value Chains.” Washington D.C.

Open Access This chapter is licensed under the terms of the Creative Commons Attribution 4.0 International License (http://creativecommons.org/licenses/ by $/ 4.0 /$ ), which permits use, sharing, adaptation, distribution and reproduction in any medium or format, as long as you give appropriate credit to the original author(s) and the source, provide a link to the Creative Commons licence and indicate if changes were made.

The images or other third party material in this chapter are included in the chapter's Creative Commons licence, unless indicated otherwise in a credit line to the material. If material is not included in the chapter's Creative Commons licence and your intended use is not permitted by statutory regulation or exceeds the permitted use, you will need to obtain permission directly from the copyright holder.

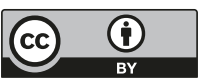

